http://jmscr.igmpublication.org/home/ ISSN (e)-2347-176x ISSN (p) 2455-0450

crossref DOI: https://dx.doi.org/10.18535/jmscr/v8i4.56

Journal Of Medical Science And Clinical Research

\title{
A Comparative Study of Surgically induced astigmatism in superior versus Supero-Temporal scleral incision in Small Incision Cataract Surgery in a tertiary eye care center in state of Odisha
}

Authors

\author{
Dr Suresh Chandra Swain, M. S ${ }^{1}$, Dr Jayaram Meher, MBBS ${ }^{2}$, Prof. P.K. Nanda, M. $\mathbf{S}^{3}$ \\ ${ }^{1}$ Associate Professor of Ophthalmology, S.C.B. Medical College, Cuttack, Odisha \\ ${ }^{2}$ Junior Resident of Ophthalmology, S.C.B. Medical College, Cuttack, Odisha \\ ${ }^{3}$ Professor \& HOD of Ophthalmology, S.C.B. Medical College, Cuttack, Odisha
}

\begin{abstract}
Aim: To evaluate \& compare the surgically induced astigmatism (SIA) in superior \& supero-temporal scleral incision in small incision cataract surgery.

Methods: This is a prospective comparative study done on a total number of 400 patients with senile cataract. 200 cases were randomly assigned superior scleral group \& other 200 cases were allotted to supero-temporal scleral incision. Small incision cataract surgery with posterior chamber intraocular lens implantation were performed. Patients were examined post operatively $1^{\text {st }}$ day, $1^{\text {st }}$ weeks, $6^{\text {th }}$ weeks \& 12 weeks. Postoperative best-corrected visual acuity \& astigmatism measured.

Results: The mean surgically induced astigmatism (SIA) in superior scleral incision is $1.35 \pm 0.44$, in super temporal group is $0.95 \pm 0.44$. In superior group mostly "against the rule astigmatism" \& in superotemporal group it is "with the rule astigmatism".

Conclusion: Supero-temporal small incision cataract surgery associated with modest astigmatism \& with the rule astigmatism contrary to superior group (against the rule astigmatism), earlier stabilization of refraction, better visual acuity.

Keywords: Astigmatism, superior incision (SI), supero-temporal incision (STI), small incision cataract surgery (SICS), With The Rule Astigmatism (WTR), Against The Rule Astigmatism (ATR), Surgically Induced Astigmatism (SIA), Visual Acuity (VA), No Astigmatism (NA).
\end{abstract}

\section{Introduction}

Cataract is the leading cause of avoidable blindness in the globe. The mainstay of the management is cataract is surgery. Although phacoemulsification has been widely applied in many centers, small incision cataract surgery remains the main approach in some under developed \& developing regions. By a virtue of its self-sealing suture less incision, lower cost of instrumentation \& disposables, it is well accepted for tackling the cataract burden in developing countries like India.

Surgically induced astigmatism (SIA) is one of the causes of the poor quality of vision postoperatively because of the blurring images. Thus control of postoperative astigmatism is a key factor in meeting these expectation. Miller Stephen $\mathbf{J}$ defined astigmatism is a condition of refraction in which a point of light cannot be made to produce a punctate image upon retina by a 
correcting spherical lens ${ }^{1}$. After cataract surgery postoperative scar cause corneal flattening along the meridian of incision \& steepening in the meridian $90^{\circ}$ away $^{2}$. SIA depends on the type, length \& position of the incision $\&$ also on the method of wound closur ${ }^{3,4}$.

\section{Materials \& Methods}

This was a prospective comparative study which was conducted between October 2017 to September 2019 in a tertiary eye care center in the state of Odisha. The patients randomly assigned to any two groups having 200 patients each. The patients in group A underwent manual SICS with superior tunnel incisions, the patients in group B underwent manual SICS with supero-temporal incisions. Both sexes included in the study. Overall 204(51\%) patients were male \& 196(49\%) were female in both the groups. The mean age group of the patients in superior scleral incision was $63.96( \pm 12.66)$ years \& in supero-temporal incision the mean age group was $64.03( \pm 10.25)$ years. Majority of patients were in the age group between 61 to 70 years.

\section{Inclusion Criteria}

All the patients with senile cortical \& nuclear cataract, posterior sub capsular cataract.

\section{Exclusion Criteria}

Patients with ocular diseases like, corneal scar, degeneration, keratoconus, pterygium, traumatic \& complicated cataract, surgical complications, diseases of glaucoma \& retina.

All the patients were pre-operatively assessed with visual acuity recording, slit-lamp biomicroscopy, tonometry \& fundus examination by using direct \& indirect ophthalmoscope, 90D lens. Astigmatism was measured by using a autorefractometer \& a keratometer. The IOL power was calculated by contact A-scan biometry by using the SRK II formula.

Preoperative investigation like a complete haemogram, random blood sugar, urine routine \& microscopy, local investigations like, intraocular pressure, syringing for sac patency was done.

\section{Surgical Procedure}

(a) Patients were operated under peribulbar local anesthesia with mixture of Xylocaine 2\%, Bupivacaine 0.5\%, Hylauronidase; (b) Superior rectus was suspended; (c) Temporal \& super temporal incision was made on bulbar conjunctiva \& stopped bleeding by cauterization; (d) Scleral frown incision was made, approximately $6.5 \mathrm{~mm}$ in size in both superior \&supero-temporal area; The central incision had distance of $1.5 \mathrm{~mm}$ from the corneosclerallimbus; (e) Scleral tunnel incision was created approximately $1 \mathrm{~mm}$ inside transparent cornea, side port entry was done by lance tip $15^{\circ}$ blade, viscoelastic agent was injected, then continuous curvilinear capsulorhexis was done; (f) Then puncture into anterior chamber \& extension of incision size inside cornea about 8mm; (g) A intraocular lens with a diameter $6 \mathrm{~mm}$ optic size, $12.5 \mathrm{~mm}$ total size was implanted after nucleus delivery \& cortex suction; (h) Self-sealing incision were kept water tight without suture. Prednisolone eye drop was administered six times daily for 1 week, then tapered over next 5 weeks. Gatifloxacin $0.3 \%$ eye drop was given six times daily for 15 days.

The patients were examined on the post-operative days $1^{\text {st }}$ day, $1^{\text {st }}$ week, $6^{\text {th }}$ week $\& 12^{\text {th }}$ week. The uncorrected \& the best corrected visual acuity were recorded; slit-lamp examination, fundus examination, autorefractometer \& keratometry examination were done. The meridians with the maximal refractive power in $90^{\circ} \pm 30^{\circ}$ was defined as "with-the rule astigmatism" $(+), \&$ the meridians with the maximal refractive power in $180^{\circ} \pm 30^{\circ}$ was defined as "against-the rule astigmatism" (-). The Surgically Induced Astigmatism (SIA) was calculated from the pre \& the post-operative Keratometric values, as described by Holladay et $\mathrm{al}^{5}$.

\section{Results}

Group-A, 200 patients superior incision; Group-B 200 patients supero-temporal incision. 
Table 1 Pre-operative visual Acuity

\begin{tabular}{|l|c|c|c|}
\hline Visual acuity & SI & STI & TOTAL \\
\hline PL+ -- CF-CR & 48 & 12 & 60 \\
\hline CF1/2Mts-CF3Mts & 44 & 64 & 108 \\
\hline CF3 $1 / 2$ Mts-CF5 $1 / 2$ Mts & 52 & 68 & 120 \\
\hline$>6 / 60$ & 56 & 56 & 112 \\
\hline Total & 200 & 200 & 400 \\
\hline
\end{tabular}

No statistical significant difference in visual acuity was found between 2 groups. $72 \%$ of the patients who underwent SICS in both groups had visual acuity less than $6 / 60,28 \%$ of the patients had had visual acuity better than $6 / 60$.

Table 2 Pre-operative Astigmatism

\begin{tabular}{|l|c|c|c|}
\hline $\begin{array}{l}\text { Type of } \\
\text { astigmatism }\end{array}$ & SI & STI & TOTAL \\
\hline WTR & $84(42 \%)$ & $68(34 \%)$ & $152(38 \%)$ \\
\hline ATR & $76(38 \%)$ & $92(46 \%)$ & $168(42 \%)$ \\
\hline NA & $40(20 \%)$ & $40(20 \%)$ & $80(20 \%)$ \\
\hline
\end{tabular}

SI group 76(38\%) ATR, 84(42\%) cases WTR, $40(20 \%)$ NA.

STI group 92(46\%) ATR, 68(34\%) WTR, 80 (20\%) NA. The average pre-operative astigmatism observed in both groups is $0.85 \mathrm{D}$.

Table 3 Post-operative Astigmatism

\begin{tabular}{|l|c|c|c|}
\hline $\begin{array}{l}\text { Type of } \\
\text { astigmatism }\end{array}$ & SI & STI & TOTAL \\
\hline WTR & $36(18 \%)$ & $172(86 \%)$ & 208 \\
\hline ATR & $160(80 \%)$ & $20(10 \%)$ & 180 \\
\hline NA & $4(2 \%)$ & $8(4 \%)$ & 12 \\
\hline Total & 200 & 200 & 400 \\
\hline
\end{tabular}

Superior incision causes more ATR shift than the WTR (80\%), where as in supero-temporal incision the shift of astigmatism was more towards WTR $(86 \%)$.

Table 4 mean surgically induced post-operative astigmatism

\begin{tabular}{|l|c|c|}
\hline SIA (D) & $\begin{array}{c}\text { SI } \\
(\text { mean } \pm \text { SD })\end{array}$ & $\begin{array}{c}\text { STI } \\
(\text { mean } \pm \text { SD })\end{array}$ \\
\hline $1^{\text {st }}$ week & $1.83( \pm 0.45)$ & $1.47( \pm 0.44)$ \\
\hline $6^{\text {th }}$ week & $1.50( \pm 0.44)$ & $1.10( \pm 0.43)$ \\
\hline $12^{\text {th }}$ week & $1.35( \pm 0.44)$ & $0.95( \pm 0.44)$ \\
\hline
\end{tabular}

This shows that most of astigmatic stabilization occurred by 12 weeks.
Table 5 Comparison of post-operative visual acuity in SI \& STI

\begin{tabular}{|l|c|c|c|c|}
\hline $\begin{array}{l}\text { Type of } \\
\text { incision }\end{array}$ & Visual acuity & $\begin{array}{c}1^{\text {st }} \\
\text { week }\end{array}$ & $\begin{array}{c}6^{\text {th }} \\
\text { week }\end{array}$ & $\begin{array}{c}12^{\text {th }} \\
\text { week }\end{array}$ \\
\hline \multirow{4}{*}{ SI } & $>6 / 9$ & 4 & 28 & 84 \\
\cline { 2 - 5 } & $6 / 18-6 / 12$ & 36 & 84 & 100 \\
\cline { 2 - 5 } & $6 / 36-6 / 24$ & 56 & 80 & 16 \\
\cline { 2 - 5 } & $<6 / 60$ & 104 & 8 & 0 \\
\hline \multirow{4}{*}{ STI } & $>6 / 9$ & 0 & 32 & 156 \\
\cline { 2 - 5 } & $6 / 18-6 / 12$ & 44 & 136 & 32 \\
\cline { 2 - 5 } & $6 / 36-6 / 24$ & 96 & 28 & 8 \\
\cline { 2 - 5 } & $<6 / 60$ & 48 & 4 & 4 \\
\hline P value & & $\mathrm{P}<0.05$ & $\mathrm{p}<0.05$ & $\mathrm{P}<0.123$ \\
\hline
\end{tabular}

The improvement in visual acuity in superotemporal group $(70 \%)$ is greater than superior group $(42 \%)$ after 12 weeks $(>6 / 9)$. The difference in both the groups is statistically significant $(\mathrm{p}<0.001)$.

\section{Discussion}

The manual small incision cataract surgery (SICS) is a good alternative to phacoemulsification at lower expenses. But SIA are higher due to large size of incision. Burgansky et $\mathrm{al}^{6}$ have shown an increase in astigmatism with increase in incision size. A pre-existing astigmatism can be neutralized by changing the site of incision. When the incision is located superiorly, both the gravity $\&$ the blinking of the eyelid tend to create a drag on incision causing "against the rule astigmatism". These forces are neutralized better with super temporally placed incision as incision is parallel to the vector of the forces ${ }^{7}$. Supero-temporal is free from the effect of gravity \& eyelid pressure \& tend to induce less astigmatism. Most patients present "with-the-rule astigmatism" Kimura et al ${ }^{8}$ have shown by vector analysis that surgically induced astigmatism is less with oblique incision $(1.02 \pm 0.66 \mathrm{D})$ than with a superior incision $(1.41 \pm 0.72 \mathrm{D})$. In our study mean SIA in group-A was found to be $1.35 \pm 0.44$, in group-B $0.95 \pm 0.44$. In the study of Gokhale et $\mathrm{al}^{9}$, the SIA in the superior group was $1.28 \mathrm{D}$, it was $0.2 \mathrm{D}$ in superotemporal group. This study found that the surgically induced astigmatism is lower superotemporal groups which is comparable to other studies. 


\section{Conclusion}

SICS with supero-temporal scleral incision produces less SIA \& "with the rule astigmatism", earlier stabilization of vision \& better visual acuity in contrast to superior incision which produces "against the rule astigmatism".

\section{References:}

1. Miller SJ, Parson's Diseases of Eye, Edinburgh: Butterworth Heinmann International Edition, $18^{\text {th }}$ edition 1990; 63-69.

2. Merriam JC, Zheng L, Merriam JE, Zaider M, Lindstrom B. The effect of incisions for cataract on corneal curvature. Ophthalmology. 2003 sep; 110(9): 180713.

3. Koch PS. The structural analysis of cataract incision construction. J Cataract Refract Surg 1991; 17(suppl): 661-67.

4. Armeniades CD, Boriek A, Knodle GE Jr. Effect of incision length, location, \& shape on local corneoscleral deformation during cataract surgery. J Cataract Refract Surg, 1990; 16(1): 83-87.

5. Holladay JT, Dudeja DR, Koch DD. Evaluating \& reporting astigmatism for individual \& aggregate Data. J Cataract Refract Surg 1998;24:57-65 (PUBMED).

6. Burgansky $\mathrm{Z}$, Isakov I, Avizemer $\mathrm{H}$, Bartov E. Minimal astigmatism after sutureless, planned extracapsular cataract extraction. J Cataract Refract Surg2002; 28:499-503.

7. Merriam JC, Zheng L, Urbanowicz J, Zaider M. Change on the horizontal \& vertical meridians of the cornea after cataract surgery. Trans Am Ophthalmol Soc.2001;99:187-95.
8. Kimura $\mathrm{H}$, Kuroda S, Mizoguchi $\mathrm{N}$, Terauchi H, Matsumura M, Nagata M. Extracapsular cataract extraction with a sutureless incision for dense cataracts. J Cataract Refract Surg 1999; 25:1275-9.

9. Gokhale NS, Sawhney S. Reduction in the astigmatism in manual small incision cataract surgery through change of incision site. Indian Journal of Ophthalmology; sept 2005;3:201. 